Arab World English Journal (AWEJ) 2 ${ }^{\text {nd }}$ Special Issue on Covid 19 Challenges January 2022

DOI: https://dx.doi.org/10.24093/awej/covid2.17

\title{
Perceptions of University Faculty of Saudi Arabia towards Online Classes Conducted During the Covid-19 Pandemic
}

Bala Swamy Chatta

Department of English, College of Sciences and Humanities

Prince Sattam Bin Abdulaziz University, Al Kharj, Saudi Arabia

Corresponding Author: b.chatta@psau.edu.sa

\author{
Mohammad Imdadul Haque \\ Department of Economics, \\ Aligarh Muslim University, India \\ M. Madhu Sudhan Rao \\ Communication Skills Division \\ Koneru Lakshmaiah Education Foundation \\ Andhra Pradesh, India
}

Received: 11/21/2021

Accepted: 12/25/2021

Published:1/24/2022

\section{Abstract}

The study aims to find out the perceptions of university faculty who taught the courses online during the Covid-19 pandemic in March 2020. The purpose is to highlight the issues of students and faculty involved in the new context of teaching and learning and prepare them to face the technical and academic challenges. A questionnaire is circulated among the faculty of universities in the Kingdom of Saudi Arabia. The majority of the university faculty who taught the courses online from the middle of the semester are satisfied with their teaching. However, they prefer face-to-face instruction to online instruction. A few of them are in favor of blended learning. The faculty accepts technical and academic issues and issues related to the trust and the value of online instruction. The study is helpful for all the educational institutions, teachers, and students across the world to understand how to conduct online education during crises and calamities to eradicate the technical and academic problems present in the online mode of teaching, and to update and accept the changing trends and developments in the field of education. The article is original because it studies the perceptions of the regular university faculty who taught half of the course face-to-face and the other half online. The novelty lies in finding out how they participated in online teaching during the lockdown period of the Covid-19 pandemic.

Keywords: Covid-19, online education, perceptions, Saudi students, strategies of instruction, teaching methods

Cite as: Chatta, B.S., Haque, M. I., \& Rao, M.M.S.(2022). Perceptions of University Faculty of Saudi Arabia towards Online Classes Conducted During the Covid-19 Pandemic. Arab World English Journal (AWEJ) $2^{\text {nd }}$ Special Issue on Covid 19 Challenges (2) 258-280.

DOI: https://dx.doi.org/10.24093/awej/covid2.17 


\section{Introduction}

Imparting of education takes place either face-to-face or online mode using technology. If a course is delivered at least $80 \%$ online, it becomes an online course (Allen \& Seaman, 2015). An online system is either synchronous or asynchronous. If faculty and students are not present simultaneously at the same place, it is asynchronous. However, if they have direct, simultaneous contact, it is viewed as synchronous (Glass, 2017). The universities deliver the courses either online or face-to-face. But, the context of March 2020 is so different. Covid-19 has impacted the world in many ways. Unexpectedly, the Covid-19 pandemic caused shutdowns of mass production companies, disruption of the supply chain, restriction of mobility and community gathering, and loss of jobs and livelihoods for millions of people (Ahadu, 2020). There came a complete and drastic change in the concept of imparting education. The faculty teaching face-toface started teaching the same course online from the middle of the semester. During the lockdown period, sanitary isolation compels people to think about online interactions and lead lives in the virtual world. This pandemic pushed academics into the virtual world, where academic discourses happened using technology.

As the education system suddenly shifted to online mode, Prince Sattam Bin Abdulaziz University, Al Kharj, trained the regular teaching faculty to handle online mode by organizing training sessions from the technical department. For this purpose, the university has provided Blackboard software, Blackboard Collaborate Ultra, to take classes, and conduct exams. The university provided training to take online courses using apps like Zoom, and social media platforms like YouTube. There are studies that say that social media is borderless, and brings about a change in society by using the congregation of the masses online. During the pandemic, the faculty used this feature in social media to manage the shift that occurred in the education sector (Al-Abdin \& Costello, 2015). Whether we use software, app, or social media, the ultimate goal of teaching is making the students receive the knowledge taught by the teacher (Fenhua \& Chenhaw, 2016).

As the regular teaching faculty started teaching the courses online from the middle of the semester, the researcher got interested in finding out their responses using a questionnaire. So far, several studies have been done on the different aspects of online education. When observed closely, the number of students joining online education rose from 1.6 million in 2002 to eight million in 2014 (Allen \& Seaman, 2015; Ladyshewsky. 2016; Tanis, 2020). Even though more and more students are taking admission in online education, $28 \%$ of faculty members do not accept the value or authenticity of online education, whereas chief academic officers buying its value rose from $43 \%$ to $74 \%$ from 2003 to 2014 (Allen \& Seaman, 2015). Studies are done in the areas of understanding online education in vocational education (Cox \& Prestige, 2020), advances, obstacles and tools of online teaching (Davis, Gough, \& Taylor, 2019; Davis, Greenaway, Moore, \& Cooper, 2019), expectations of students in online education (Bailie, 2015; Wyss, Freedman \& Siebert, 2014), student-instructor relationship (Joyner et al., 2014), interaction between teacher and students (Wallace, 2003; Conaway, Easton \& Schmidt, 2005; Stone \& Springer, 2019), student feedback of online classes (Paquette, Corbett \& Casses, 2015), 
student responses to online course materials (Matthew, 2001), student responses to online peer assessment (Yang, 2019), student perceptions of online classes (Benino, Girardi, Czarniak, 2011; Alsaif, 2019), using effective assessment techniques of online education (Vonderwell \& Boboc, 2013; Peterson, 2016; Dutton, Ryznar \& Long, 2019), principles of effective online teaching (Cable \& Cheung, 2017), designing the online courses (Reeves \& Reeves, 2008; Power \& Jacques, 2014; Kibaru, 2018), measuring the community in online classes (Rubin \& Fernandes, 2013), and comparing face-to-face education with online education (Hartley \& McGanghey, 2018; Bolsen, Evans \& Fleming, 2016; Morrison, 2011; Wong \& Tatnall, 2009).

But, very few studies are available where the education system took a complete shift from face-to-face to online mode. Therefore, the present study is about the reactions of the regular university face-to-face teaching faculty who are suddenly pushed into online faculty in the middle of the semester due to the Covid-19. The researcher made a study on the feedback of the regular faculty who taught the courses online. The research questions include:

1. Are the face-to-face teaching faculty mentally ready to teach online in the Kingdom of Saudi Arabia (KSA)?

2. Do the faculty have technical skills sufficient to handle online classes and exams?

3. What are the issues or problems in teaching a course online and face-to-face in the same semester?

The objectives of these research questions are to find out the attitudes of the regular face to

face teaching faculty towards the sudden

shift to online teaching, and whether they possess the technical skills necessary for the conduction of online classes, and to find out the problems involved in these two modes of teaching.

\section{Literature Review}

Quality education depends upon effective teaching, which is the result of a better teaching-learning system (Ahmmad, 2014). Several studies are conducted worldwide to find out the better online teaching-learning system.

Al-Samiri (2021) explored the positive and negative impact of the pandemic at tertiary level teaching and learning due to the shift to online teaching. He did a review of research published since the pandemic and analyzed the problems faced by students and faculty. The study revealed that there were some problems like students' lack of motivation, technological issues, inapt learning environment and students' mental health. There were also some positive outcomes like flexibility of place and time.

Daraghmeh, Mead, and Copeland (2021) examined the impact of the pandemic in K-12 English instruction in the MENA region of Saudi Arabia. The study explored technological, institutional and socio-cultural factors faced by Khbrat English teacher graduates. The results revealed that it has both positive and negative effects. 
Tanis (2020) received feedback from 14 college faculty and 111 alumni from the same graduate program on the importance of teaching and learning online and proposed seven principles for online learning. The study demonstrated that the most important factor for both faculty and students was the commitment to high standard performance, honesty in academics, and professional conduct. The alumni responded that the interaction with the faculty was more valuable than peer interaction.

Davis et al. (2019) conducted a study to understand the challenges of online teaching in social work education in Australia. The study reveals the challenges of instructors in course outcomes, retention of students, and active student engagement in the classes. To meet these challenges, academics need to become aware of the best practices in distance education and online education, and implement them with the best technical skills.

Annamalai (2019) did a study on massive open online courses in Malaysian higher education and found out the perceptions of the lecturers regarding online education. He interviewed 15 lecturers who have expertise with online education. The findings demonstrated that the lecturers are well aware of the transition of education from traditional to online. He also explored the challenges of integrating massive open online courses in higher education institutions. The study concludes that the lecturers are not rejecting technology, but feel that online education is taking away the pedagogical considerations.

Czerniewicz et al. (2019) conducted interviews with the educators of the University of Cape Town to find out their views, practices, and experiences of handling the online classes during the crisis from 2015 to 2017 in South Africa. During this period, the authorities closed universities due to the student protests caused by student prohibition based on financial, epistemological, and cultural grounds. In these highly disturbing times, some universities decided to conduct online classes to complete the academic year. The study revealed that the instructors had mixed feelings about the demonstrations, and they felt that blended learning or online learning exacerbates the feelings of inequality. The instructors also felt that conducting online classes during the protests may show the university in a bad light.

Barnett (2019) conducted a study in a university in the United States to determine the relationship between transformational, transactional, and laissez-faire leadership behaviors and online teaching adjunct faculty's extra effort, as there is an increased demand for online courses from the students. The results showed that these leadership styles had a tremendous positive influence on the extra efforts of the adjunct faculty. The researcher also finds that job satisfaction of these faculties is a partial mediator between the leadership style and the extra effort.

Carpenter and Spadaro (2019) explored the challenges confronted by the faculty in a communication department, which moved the undergraduate program to online mode. The study focused on the issues of the faculty to handle both online and face-to-face classes and how they employed flexible hybrid course structures. The instructors of the courses discovered innovative 
methods to build faculty-student and student-student relationships. The findings reveal that many students have opted for online courses, even though face-to-face classes are available. The faculty in the department took it as an opportunity to learn and be transformed to serve both sets of students.

Muljana and Luo (2019) made a literature review of 40 studies on the conduction of online courses from 2010 to 2018 regarding the factors that influenced the growing popularity of online classes and their completion rate. The study revealed that factors like support from the institutions, the standard of the courses, creating a sense of belonging, support received for learning, course structure, and personal behavior of students influence student retention rate. They have identified strategies to increase the student retention rate. The plans include supporting from the beginning of the course, employing effective communication, supporting the online faculty, quality feedback strategies, guiding students towards positive behavior, and stakeholders' collaboration.

Chen and Liu (2018) focused on the self-assessment of online teaching faculty on their course designs. In the study, they demonstrated two types of self assessment such as weekly discussion posts and end-of-semester oral examinations. The academics made a self-assessment and redesigned their courses and activities. The redesigning of the curriculum and activities improved student performance.

While many aspects of online learning are explored by various scholars, there exists no consensus among counselor educators regarding the best practices of online education. Foster, Neuer and Briggs (2018) worked to improve the effectiveness of the online pedagogy to the maximum by suggesting supportive language which is appropriate and warm to impart knowledge and inspire the online students.

Paolo, Wakefield, Mills and Baker (2017) studied how to incorporate video into online classes. They have considered the pedagogical and technological issues related to steps in educational video design such as planning, development, delivery, and reflection. The research concludes that video is an excellent tool to introduce, model, inform, and give feedback.

Glass (2017) explored the differences between the opinions of faculty members and chief academic officers towards online education. His research finds that if faculty members are allotted the required number of classes as per their interests and skills, they would perform better rather than allocating the same number of classes to all. His research also focuses on how different faculty teaching the same course has different experiences of teaching the course.

Ladyshewsky (2016) reported the experience of a senior off-site faculty member working within a virtual environment with evidence that this type of working arrangement can be very successful for universities. His success is due to his intrapersonal skills, his work experience, and 
the technology-rich university environment. He maintained excellent communication with his colleagues who were also teaching business.

Sher, Williams, and Northcote (2015) studied the experiences of online academics teaching construction management in Australian universities. These faculty design, develop, train, facilitate and administer online courses. These additional tasks are becoming hectic for managing their teaching and professional development. This study exposes the challenges faced by these academics. The faculty revealed that most of them are self-taught, and reluctant to teach online due to the lack of resources and skills.

Ahmmad (2014) studied the issues of teachers for effective teaching in government colleges of Dhaka. Some of the problems are nonavailability of modern teaching aids, unable to follow a particular teaching method, not preparing regular lesson plans, the scarcity of trained teachers, nonsupportive authorities, and political instability. The research proposes some recommendations to ensure effective and efficient delivery of classroom teaching.

Gorsky and Blau (2009) analyzed an exceptional situation where after completing an online distance education course, one faculty received the highest feedback, and the other faculty received the lowest feedback from students. They suggested best practices for active participation, instructor response time, and the role of teaching presence, social presence, and cognitive presence.

Chen \& Chen (2006) circulated a questionnaire to find out the attitudes of university online teaching faculty in human resources in Taiwan. They used the theory of reasoned action for the purpose. The study revealed that the university faculty possessed a positive attitude towards the conduction of the online classes, and they supported using the theory of reasoned action.

Ali et al. (2005) assessed the needs of online teaching faculty of the College of Applied Science and Technology in a Midwestern university. They have surveyed to identify their expertise level in teaching the online and areas to address in the faculty development programs. Their results reveal that the expertise of online teaching faculty ranged from advanced beginner to competent. Still, the faculty who had no experience of teaching online ranged from novice to advanced beginner.

\section{Methods}

\section{Participants}

Participants of the study include 63 teaching faculty from Prince Sattam Bin Abdulaziz University (PSAU), and 40 from other universities of Saudi Arabia. Out of 103 respondents, 25 are Saudi or Arab nationals and 78 are non-Arab nationals teaching in the universities of Saudi Arabia. Male faculty are 92, and female faculty are 11. As per the designation of the respondents, 
Arab World English Journal (AWEJ) 2nd Special Issue on Covid 19 Challenges January 2022

lecturers are 39, assistant professors are 46, associate professors are 15, and professors are 3 . The table one shows the details of the respondents.

Table 1. Participants sample selection

\begin{tabular}{|l|l|l|}
\hline Characteristics & Category & Number \\
\hline \multirow{3}{*}{ Nationality } & Saudi or Arab national & 25 \\
\cline { 2 - 3 } & Non Arab national & 78 \\
\hline \multirow{3}{*}{ Gender } & \multirow{2}{*}{ Male } & 92 \\
\hline \multirow{3}{*}{ University } & Female & 11 \\
\hline \multirow{4}{*}{ Designation } & PSAU & 63 \\
\cline { 2 - 3 } & Others & 40 \\
\hline & Lecturer & 39 \\
\cline { 2 - 3 } & Assistant Professor & 46 \\
\cline { 2 - 3 } & Associate Professor & 15 \\
\cline { 2 - 3 } & Professor & 3 \\
\hline
\end{tabular}

\section{Collection of the Data and Data Analysis}

The researcher collected the required data using a questionnaire. He prepared and circulated the questionnaire among the university teaching fraternity of Saudi Arabia. In the first section of the questionnaire, respondent details are asked, and in the second part, 15 questions with a five-point Likert scale that ranges from 'strongly disagree' to 'strongly agree' are given. The first five questions are related to student issues, the following five questions are related to faculty issues, and the last five questions are general.

\section{Data Analysis}

At the end of the semester, after the conduction of final examinations, the researcher circulated a questionnaire through Google Docs to find out the responses of the faculty who taught the course online. The received data is evaluated using SPSS 16. To test the internal consistency of the 15 items of the questionnaire, Cronbach's Alpha is calculated to be 0.767, which is an excellent level for the internal consistency of the items. Hence, the questionnaire is proved to be reliable. The reliability coefficient of the questionnaire is given in the following table two:

Table 2. Reliability Statistics of the questionnaire

\begin{tabular}{|l|l|l|}
\hline \multicolumn{3}{|l|}{ Reliability Statistics } \\
\hline Cronbach's Alpha & $\begin{array}{l}\text { Cronbach's Alpha Based on } \\
\text { Standardized Items }\end{array}$ & N of Items \\
\hline 0.774 & 0.767 & 15 \\
\hline
\end{tabular}

\section{Findings}

The analysis of the questionnaire helped the researcher to understand the personal attitudes and responses of the faculty. Online teaching helped the faculty to complete the 
remaining syllabus and conduct final examinations by using the Blackboard portal. The answers of the faculty for four questions in the first section of the questionnaire are shown in the following figure one.

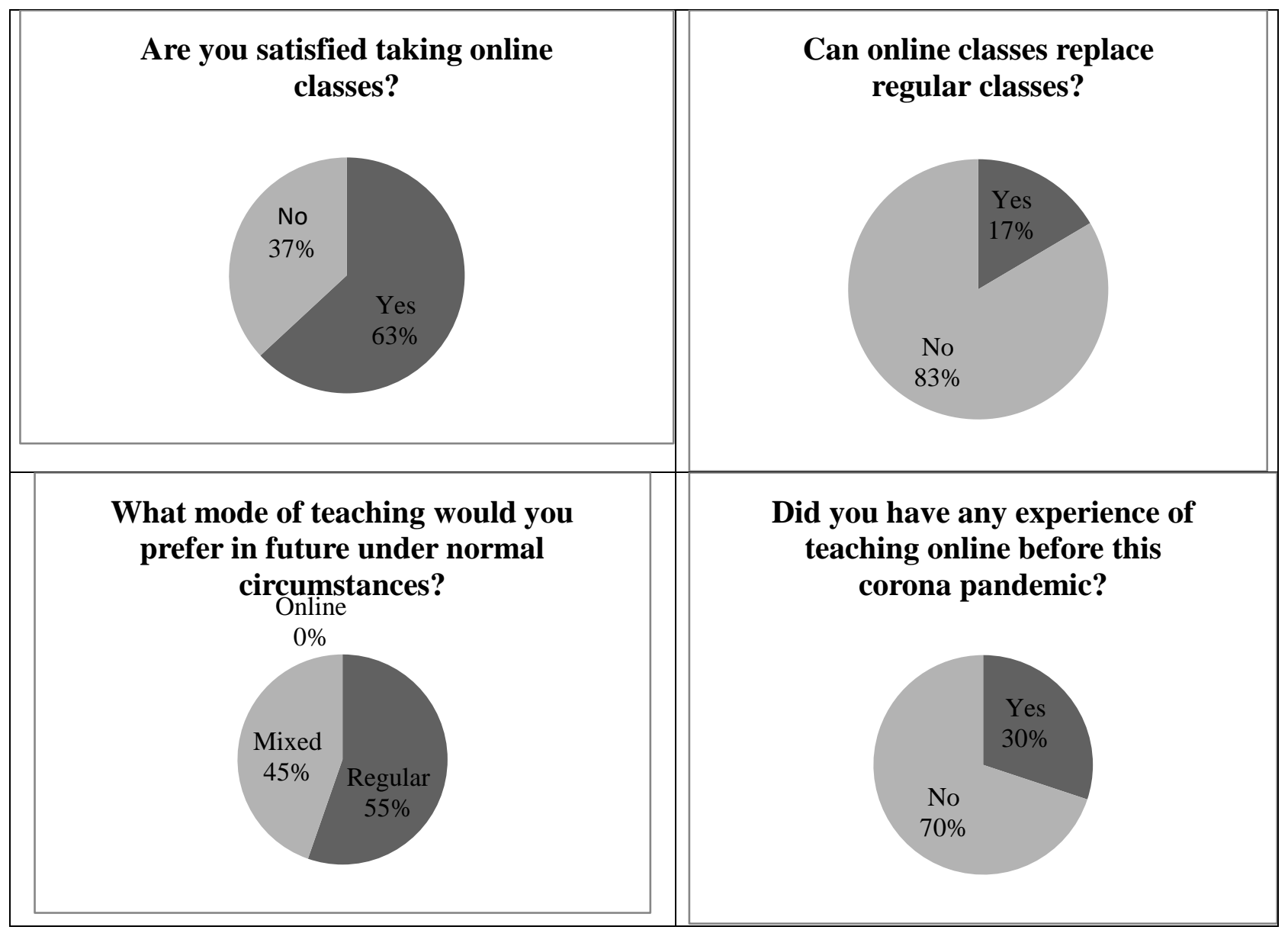

Figure 1. The responses of the faculty for four questions in the first section As figure one depicts, $70 \%$ of respondents do not have any previous online teaching experience. Due to the training sessions provided by the university and the self-learning of the faculty, they could complete the syllabus and conduct final examinations online. The online classes have given satisfaction to $63 \%$, but $83 \%$ of the faculty feel that online classes cannot replace regular classes. This response means that the faculty possess the skillset to handle online classes. However, they don't believe that online classes can replace regular classes. When asked about their preferred mode of teaching in normal circumstances, 55\% of them voted for regular mode, and only $45 \%$ of them prefer mixed mode of teaching, and no one wants to have online mode alone. It's a clear indication that online teaching is a tool used by the faculty during the crisis, but they do not support it under normal conditions. 
The second section of the questionnaire contains 15 items for which mean, mode, standard deviation, skewness and kurtosis are calculated and given in the Appendix A. It depicts the descriptive statistics of the statements used. Except for Item 13, all the statements had a mean score of more than three, indicating agreement to the statements. In fact, except for item 13, the median score is four. Again all the items except 14 are negatively skewed, indicating values are concentrated on the right side.

The first five questions of the questionnaire contain student-related issues. The percentages from 'strongly disagree' to strongly agree' are given in the table three.

Table 3: Student related issues

\begin{tabular}{|c|c|c|c|c|c|c|c|c|c|c|}
\hline & \multicolumn{2}{|c|}{ Item 1 } & \multicolumn{2}{c|}{ Item 2 } & \multicolumn{2}{c|}{ Item 3 } & \multicolumn{2}{c|}{ Item 4 } & \multicolumn{2}{c|}{ Item 5 } \\
\hline & No. & $\%$ & No. & $\%$ & No. & $\%$ & No. & $\%$ & No. & $\%$ \\
\hline Strongly Disagree & 2 & 1.94 & 5 & 4.85 & 2 & 1.94 & 5 & 4.85 & 4 & 3.88 \\
\hline Disagree & 20 & 19.42 & 16 & 15.53 & 9 & 8.74 & 25 & 24.27 & 12 & 11.65 \\
\hline Neutral & 16 & 15.53 & 10 & 9.71 & 3 & 2.91 & 20 & 19.42 & 7 & 6.80 \\
\hline Agree & 45 & 43.69 & 54 & 52.43 & 52 & 50.49 & 40 & 38.83 & 58 & 56.31 \\
\hline Strongly Agree & 20 & 19.42 & 18 & 17.48 & 37 & 35.92 & 13 & 12.62 & 22 & 21.36 \\
\hline
\end{tabular}

The table three depicts that more faculty voted for 'agree' and 'strongly agree.' It means that faculty believe that students have issues attending online classes. The problems are the seriousness of the students, inability to interact with students, distractions of students connected with mobiles, the boredom of students, and lack of peer interaction, and learning. As many faculty believe that these issues exist for students, they have not voted for online classes, and only $45 \%$ of them voted for mixed-mode. Similarly, faculty also have issues in conducting the online classes. The percentages of each item from item 6 to item 10 are given in the following table four.

Table 4. Faculty related issues

\begin{tabular}{|c|c|c|c|c|c|c|c|c|c|c|}
\hline \multirow[t]{2}{*}{ Items } & \multicolumn{2}{|c|}{ Item 6} & \multicolumn{2}{|c|}{ Item 7} & \multicolumn{2}{|c|}{ Item 8} & \multicolumn{2}{|c|}{ Item 9} & \multicolumn{2}{|c|}{ Item 10} \\
\hline & No. & $\%$ & No. & $\%$ & No. & $\%$ & No. & $\%$ & No. & $\%$ \\
\hline Strongly Disagree & 3 & 2.91 & 4 & 3.88 & 4 & 3.88 & 3 & 2.91 & 5 & 4.85 \\
\hline Disagree & 15 & 14.56 & 24 & 23.30 & 15 & 14.56 & 32 & 31.07 & 12 & 11.65 \\
\hline Neutral & 9 & 8.74 & 19 & 18.45 & 17 & 16.50 & 22 & 21.36 & 15 & 14.56 \\
\hline Agree & 39 & 37.86 & 42 & 40.78 & 41 & 39.81 & 36 & 34.95 & 53 & 51.46 \\
\hline Strongly Agree & 37 & 35.92 & 14 & 13.59 & 26 & 25.24 & 10 & 9.71 & 18 & 17.48 \\
\hline
\end{tabular}


Table four depicts that more faculty voted for 'agree' and strongly agree.' This clearly indicates that faculty issues also exist in conducting online classes. The issues are the inability to answer the questions of students and clear their doubts, the fatigue and stress created by the computer screen, which leads to boredom and drowsiness, frustrating internet problems, and floppiness of the monitoring testing process. As all these problems existed, $83 \%$ of the faculty said that online classes are ineffective and cannot replace regular classes.

Similarly, percentages are calculated for items 11 to 15 , and shown in the following table five

Table 5. General observations

\begin{tabular}{|l|l|l|l|l|l|l|l|l|l|l|}
\hline & \multicolumn{3}{|l|}{ Item 11} & \multicolumn{2}{l|}{ Item 12 } & \multicolumn{2}{l|}{ Item 13} & \multicolumn{2}{l|}{ Item 14} & \multicolumn{2}{l|}{ Item 15 } \\
\hline & No. & $\%$ & No. & $\%$ & No. & $\%$ & No. & $\%$ & No. & $\%$ \\
\hline Strongly Disagree & 10 & 9.71 & 3 & 2.91 & 50 & 48.54 & 6 & 5.83 & 6 & 5.83 \\
\hline Disagree & 18 & 17.48 & 2 & 1.94 & 35 & 33.98 & 26 & 25.24 & 20 & 19.42 \\
\hline Neutral & 12 & 11.65 & 6 & 5.83 & 11 & 10.68 & 22 & 21.36 & 23 & 22.33 \\
\hline Agree & 46 & 44.66 & 55 & 53.40 & 7 & 6.80 & 40 & 38.83 & 42 & 40.78 \\
\hline Strongly Agree & 17 & 16.50 & 37 & 35.92 & 0 & 0.00 & 9 & 8.74 & 12 & 11.65 \\
\hline
\end{tabular}

As the above table five demonstrates, more percentage of faculty chose 'agree' and 'strongly agree' for items 11, 12, 14 and 15. It means that class size is not an issue in online teaching. Even in extreme conditions like pandemics or war, teaching can be continued, traveling time is saved for all, online teaching is convenient and flexible. Only for item 13, more percentage of faculty have chosen 'strongly disagree' and 'disagree,' which means that online teaching is not a substitute for regular teaching.

The relation of nationality, gender, and prior experience to each item is calculated (See Appendix B). There is a significant difference between nationality and Item four. Similarly, there is a significant difference between gender and Item 13. And also, there is a significant difference between prior online teaching experience and Items three, four, five, six, seven and nine.

Additionally, the researcher analyzed how designation and university of faculty influence each item (See Appendix C). There is no significant difference between different designations as far as the 15 items are concerned as all the p-values are more than 0.10 . Also, except for Item 11, there is no significant difference across universities for the remaining 14 items. Item 11 has a pvalue of 0.085 , which is less than 0.10 , making the difference across universities significant. The relation among satisfaction, replacement, and selection of future mode for each item is calculated (See Appendix D). There is a significant difference between satisfaction from online teaching and Item 1,2,3,5,6,7,8,9,14,15. And also, there is a significant difference between the respondents with the perception that online teaching can replace regular teaching and Item 
Arab World English Journal (AWEJ) 2nd Special Issue on Covid 19 Challenges January 2022

$1,2,3,4,5,6,7,8,9,10,13,15$. There is a significant difference between the preference for mode of teaching in the future and Item $1,2,3,4,5,6,7,8,9,10,13,15$

An analysis is done to find whether the software used for teaching online classes has any differences in the faculty satisfaction.

Table 6. Software and satisfaction

\begin{tabular}{|l|l|l|l|l|l|}
\hline Item & $\mathrm{N}$ & Mean & Std. Deviation & F & Sig. \\
\cline { 1 - 3 } Blackboard & 79 & 1.3291 & 0.47289 & & \\
\cline { 1 - 3 } Zoom & 16 & 1.5625 & 0.51235 & \multirow{2}{*}{0.559} & \multirow{2}{*}{0.215} \\
\cline { 1 - 3 } Others & 8 & 1.375 & 0.51755 & \\
\cline { 1 - 3 } Total & 103 & 1.3689 & 0.48487 & & \\
\cline { 1 - 4 }
\end{tabular}

The analysis shows no difference between the software platform used and the satisfaction from online teaching.

\section{Factor Analysis}

It is an entirely new phenomenon as the Covid-19 pandemic forced online teaching. Hence, the study attempts to develop a scale. Towards this, the study does Exploratory Factor Analysis. In addition, the Kaiser-Meyer-Olkin Measure of Sampling Adequacy is 0.864, and the chi-square for Bartlett's Test of Sphericity is significant, which indicates that the model is adequate. The sample size is sufficient (Table 7).

Table 7: KMO and Bartlett's Test

\begin{tabular}{|l|l|l|}
\hline KMO and Bartlett's Test & & 0.864 \\
\hline Kaiser-Meyer-Olkin Measure of Sampling Adequacy. & Approx. Chi-Square & 739.054 \\
\hline Bartlett's Test of Sphericity & Df & 105 \\
\hline & Sig. & 0 \\
\hline
\end{tabular}

The fifteen statements are subjected to varimax rotation to make fewer latent variables. The results indicate that these three latent variables capture 61.35 percent of the variance. (Table 7). The first latent variable consists of nine items. These items are:-Students are not serious during the online classes; Interacting with students during the online classes is difficult; Monitoring students and their non-academic activities during online classes are a big issue; Online classes can have physical and mental health issues; Peer learning and peer interaction is missing in online classes; Monitoring the testing process is not effective in online mode; The learning process is not effective in online mode; Online teaching should be used only in emergencies; Online teaching is a substitute for regular teaching. The latent factor comprising of these items can be identified as the learning process. This factor explains $32.48 \%$ of the variance. All factor loadings are positive except that 'Online teaching is a substitute for regular teaching'. 
Arab World English Journal (AWEJ) 2nd Special Issue on Covid 19 Challenges January 2022

Perceptions of University Faculty of Saudi Arabia towards Online Classes

Chatta, Haque \& Rao

Table 8: Total variances

\begin{tabular}{|c|c|c|c|c|c|c|c|c|c|}
\hline \multirow{2}{*}{$\begin{array}{l}\text { S.N } \\
\text { o }\end{array}$} & \multicolumn{4}{|c|}{ Initial Eigenvalues } & \multicolumn{2}{|c|}{ Extraction Sums of Squared Loadings } & \multicolumn{3}{|c|}{ Rotation Sums of Squared Loadings } \\
\hline & Total & $\begin{array}{l}\text { \% of } \\
\text { Varianc } \\
\mathrm{e}\end{array}$ & $\begin{array}{l}\text { Cumulativ } \\
\text { e } \%\end{array}$ & Total & $\begin{array}{l}\% \text { of } \\
\text { Varian } \\
\text { ce }\end{array}$ & Cumulative $\%$ & Total & $\begin{array}{l}\% \text { of } \\
\text { Variance }\end{array}$ & Cumulative $\%$ \\
\hline 1 & 6.385 & 42.567 & 42.567 & 6.385 & 42.567 & 42.567 & 4.872 & 32.478 & 32.478 \\
\hline 2 & 1.653 & 11.021 & 53.589 & 1.653 & 11.021 & 53.589 & 2.67 & 17.8 & 50.278 \\
\hline 3 & 1.165 & 7.764 & 61.353 & 1.165 & 7.764 & 61.353 & 1.661 & 11.074 & 61.353 \\
\hline 4 & 0.974 & 6.49 & 67.843 & & & & & & \\
\hline 5 & 0.76 & 5.068 & 72.91 & & & & & & \\
\hline 6 & 0.715 & 4.768 & 77.678 & & & & & & \\
\hline 7 & 0.594 & 3.958 & 81.636 & & & & & & \\
\hline 8 & 0.515 & 3.431 & 85.067 & & & & & & \\
\hline 9 & 0.438 & 2.919 & 87.987 & & & & & & \\
\hline 10 & 0.404 & 2.691 & 90.678 & & & & & & \\
\hline 11 & 0.373 & 2.484 & 93.162 & & & & & & \\
\hline 12 & 0.344 & 2.296 & 95.458 & & & & & & \\
\hline 13 & 0.315 & 2.097 & 97.556 & & & & & & \\
\hline 14 & 0.218 & 1.455 & 99.011 & & & & & & \\
\hline 15 & 0.148 & 0.989 & 100 & & & & & & \\
\hline
\end{tabular}

The second latent factor comprises of Online teaching is boring and monotonous; Internet issues are very frustrating; The traveling time saved in online mode for faculty and students is worth it; Online teaching is convenient and flexible. The latent factor can be named as teaching factors. This latent variable explains 17.8 percent of the variance.

Table 9. Rotated Component Matrix

\begin{tabular}{|l|l|l|l|}
\hline Variables & \multicolumn{3}{|c|}{ Component } \\
\hline & 1 & 2 & 3 \\
\hline VAR00003 & 0.822 & & \\
\hline VAR00006 & 0.775 & & \\
\hline VAR00005 & 0.769 & & \\
\hline VAR00007 & 0.755 & & \\
\hline VAR00002 & 0.696 & & \\
\hline VAR00004 & 0.658 & & \\
\hline VAR00008 & 0.642 & & \\
\hline VAR00013 & -0.564 & & \\
\hline VAR00001 & 0.544 & & \\
\hline VAR00015 & & -0.813 & \\
\hline VAR00014 & & -0.729 & \\
\hline
\end{tabular}

Arab World English Journal

ISSN: 2229-9327 
Arab World English Journal (AWEJ) 2nd Special Issue on Covid 19 Challenges January 2022

\begin{tabular}{|l|l|l|l|}
\hline VAR00009 & & 0.602 & \\
\hline VAR00010 & & 0.521 & \\
\hline VAR00011 & & & 0.845 \\
\hline VAR00012 & & & 0.753 \\
\hline
\end{tabular}

The third latent variable comprises of class size is not an issue in online mode; and teaching can be continued in extreme situations like pandemics, war, etc. This latent factor can be named administration. This latent variable explains 11.07 percent of the variance (Table 9).

\section{Discussion}

The study demonstrates that the regular university teaching faculty of Saudi Arabia favor face-to-face mode of teaching rather than online teaching. The faculty have the necessary technical and management skills to handle online classes. Still majority of them find that the student-related issues and faculty-related issues act as a stumbling block to delivering the online classes effectively. Thus, research question one is answered that the regular university faculty of KSA possess the skills to take online classes, but they don't believe in their efficiency. As all the respondents took the online classes during the pandemic and are comfortable handling the softwares, research question two is answered that the faculty possess sufficient technical skills to handle synchronous and asynchronous online classes. The faculty is well aware of studentrelated issues and faculty-related issues faced during the online sessions. Hence, the research question three is answered that there are issues regarding technology, the process of teaching, time allocation, the effectiveness of delivery, and technical glitches during tests.

The results of the present study are in line with the findings of Tanis (2020) that students and faculty should be committed and honest to make online classes successful. Or else, boredom, fatigue, and stress reduce the effectiveness. The challenges of online teaching presented by Daraghmeh et al. (2021), Al-Samiri (2021) and Davis et al. (2019) are similar to the present study. As the social work education faculty of Australia felt, the faculty working in KSA also felt that there are issues with course delivery and active engagement of students.

The perceptions of online lecturers in the study of Annamalai (2019) and the perceptions of the faculty working in KSA agree with each other. The faculty are not opposed to technology, but they give priority to pedagogical considerations, and given a chance, would like to go for face-to-face teaching.

The context of Czerniewicz et al. (2019) is quite similar to the present study because both studies are done during the crisis. If the regular faculty are expected to teach online, they take time to accept the validity and effectiveness of the courses. In both cases, the faculty completed the syllabus and helped students attempt examinations. Nevertheless, they are in favor of face-toface teaching. 
The results are also in agreement with the findings of Barnett (2019), who focused on leadership styles and extra effort of the faculty. In the present study, the faculty took extra effort to learn technology and take online classes. The faculty took leadership at their levels in helping others and cooperating with the new system.

As the faculty of communication department in the study of Carpenter and Spadaro (2019) molded themselves to confront the challenges of a newly converted online undergraduate program, so do the faculty of KSA in the present study. The strategies used by the faculty, in the study of Muljana and Luo (2019), such as effective communication, quality feedback, and guiding students to exhibit positive behavior, are also used by the faculty to handle the online classes. A similar strategy of using supportive language as expressed in the study of Foster et al. (2018) and active participation and giving timely response found in Gorsky and Blau (2009) are employed by the faculty of the current study in their daily online classes.

Unlike the faculty in the research of Chen and Liu (2018), who took self-assessment weekly and at the end of the semester, no formal evaluation is conducted for the faculty performance in the present study. There could be informal feedback from the students in every class, which helped the faculty complete the courses successfully.

As declared by Paolo et al. (2017) that a video is an effective tool in online education, the Blackboard Collaborate Ultra software creates the video after the classes and makes them available to students all the time. The teaching videos helped students rewind the missing classes and prepare for the tests.

At Prince Sattam Bin Abdulaziz University, the teaching workload and courses are allotted to the faculty with their knowledge and agreement in the beginning of the semester. So, the results align with the study of Glass (2017).

There is an ocular proof for the existing technical knowledge of the students. As Junior and Lemos (2017) have reported, an online protest 'Do not close my school' is run by secondary education students in Brazil using Facebook. The movement is carried against the closure of 94 schools of the public educational system. Similarly, the lockdown period of the Covid-19 pandemic has brought out the abundance of technical skills of the university faculty in Saudi Arabia.

The role of a senior off-site faculty member in the study of Ladyshewsky (2016) is played by the technical department in PSAU. They assisted the faculty continuously in training the faculty in the usage of online classes, softwares, and conduction of examinations. They were available all the time to answer the questions and clarify the doubts of the faculty.

The results of the present study are contradicting with the study of Sher et al. (2015) in the sense that faculty in KSA are provided with sufficient resources and technical help to handle 
online classes. But, the faculty in both studies feel that face-to-face teaching is better than online teaching.

When the present study is compared to the study of Ahmmad (2014) regarding the issues of faculty, it is observed that the problems of faculty in Dhaka and Saudi Arabia are not the same. The problems of teachers in Dhaka are related to political and managerial issues, but the problems of teachers of Saudi Arabia are more academic and technical. Therefore, the recommendations provided for these two studies are also different.

As $63 \%$ of faculty are satisfied with their online teaching experience, the results of Chen $\&$ Chen (2006) are similar to the present study. In both studies, the faculty are positive towards online education.

Ali et al. (2005) predicted that courses would become online in the future. Their prediction became a reality as many universities offer online education in 2020 . Due to the Covid-19, the entire education system started teaching online. The results of the present study agree with this study as they said continuous training should be provided to faculty, who are teaching online now and who would teach online in the future. So, there should be many opportunities for faculty development in online education. In the present study, only $30 \%$ of faculty have expertise ranging from advanced beginner to competent as they have previous experience. The rest $70 \%$ of the faculty can be grouped under novice to an advanced beginner as they taught the online courses the first time. So the study of Ali et al. (2005) is applicable in the present study also.

Finally, the method of exploratory factor analysis helps in the formation of a scale to measure faculty members' attitudes towards online teaching. The study identifies the learning process, teaching factors, and administration. Testing this scale for reliability in the future studies with a sample of different countries and the different universities would be the scope of future research. Online teaching is a substitute for regular teaching (Item 13), the traveling time saved in online mode for faculty and students is worth it (Item 14), and online teaching is convenient and flexible (Item 15) has a negative factor loading. Item 13 and item 15 indicate the negative perception of faculty members towards online teaching.

\section{Conclusions}

The Covid-19 pandemic has brought many changes in society, and it has hugely affected the lives of many individuals. As the universities in KSA always support the benefit of the students, they shifted face-to-face classes to online classes. Most of the university faculty do not have prior experience teaching courses online. Therefore, the technical departments of the universities took it as a challenge to train the regular university faculty to complete the syllabi and conduct the remaining tests online. Due to the continuous support provided by the technical staff, the faculty could complete the semester successfully. As the analysis shows, the majority of the faculty conducted the online classes to their satisfaction and expectation of the students. 
However, the faculty feel that online mode may rescue the education system during a crisis like a pandemic, and it is only a temporary solution. Once the situation becomes normal, they prefer to have the face-to-face mode of teaching.

Technical issues are always present in the online mode of teaching. The faculty can avoid them by taking proper guidance from the technical staff, and giving importance to self-learning. As the present students are digital natives, they choose more and more technology to be included in the classroom and the education field. Across the world, the number of students choosing online education is increasing day by day. A country like KSA provides many opportunities to the students for using technology in and outside of their classes and supports student learning at any cost.

\section{Recommendations}

The experts in the educational field feel that there will be a coexistence of online and offline education. Hence, the present study recommends the implementation of blended learning in every course up to 20 percent. It prepares both teachers and students to feel comfortable with any type of teaching and learning during any calamity like the pandemic. Offline campuses will have to include online components as it is the fastest-growing segment of higher education supported by the technical giants.

The universities should incorporate technology more and more to support the students' learning. The effective implementation of this feature can change the negative perspective of regular faculty towards online teaching. The key determinant of quality in online education is regular, and substantive student-instructor interactivity which leads to improved student satisfaction, learning, and outcomes. Technology makes it possible for teachers and students to be constantly in touch with each other and have academic interactions.

The researcher conducted the present study in and around PSAU in Saudi Arabia, who had only a few weeks of online teaching experience. More studies should be conducted with faculty with more experience and in different parts of the world. This is possible due to the omnipresence of the pandemic across the nations, and in most of the countries, the education system is shifted to online mode during the crisis like KSA.

Faculty and academic leaders, employers and the general public are doubtful about the quality, and value of online education. They consider online teaching inferior to face-to-face instruction. The universities in and around KSA should allocate more time and funds to train the faculty in using technology in and outside the classroom as the coexistence of online and offline education is the present trend. This will enable more faculty to cultivate a positive attitude towards the new trends of education delivery, and they may remain up to date to cater to the needs of the present generation. 
Participating in online education is still a costly affair for poor students. Procuring advanced technical gadgets, and maintaining continuous internet connection are big hurdles for the poor sections of society. So the universities and governments must take steps to support these students, and make it possible for them to be part of the education system. Education should become a right for every student whatever is his financial position.

\title{
Acknowledgments
}

The author would like to thank the Scientific Research Wing of Prince Sattam Bin Abdulaziz University, Al Kharj, for their continuous support.

\begin{abstract}
About the Author
Bala Swamy Chatta is a lecturer in the Department of English, Prince Sattam bin Abdulaziz University, Al Kharj, Kingdom of Saudi Arabia. He has 17 years of experience in teaching English in various colleges and universities. He is an expert in English literature, teaching LSRW skills and Grammar. He has published around twelve research papers in various international journals in the areas of literature and ELT.
\end{abstract}

ORCID: https://orcid.org/0000-0001-7269-2649

Dr. Md Imdadul Haque is an Associate Professor at the Department of Economics, Aligarh Muslim University, India. Earlier he worked as Associate Professor at Prince Sattam Bin Abdulaziz University, Kingdom of Saudi Arabia. He has over fourteen years of teaching and research experience at the local and international levels. During this period, he has published more than fifty research papers in journals of international repute; and has presented over a dozen papers at national and international conferences. Recently he found research interest in the teaching and testing process. ORCiD ID: https://orcid.org/0000-0001-6323-032X

Dr. Munagala Madhu Sudhan Rao has been working as Head \& Associate Professor of English in Communication Skills Division, Koneru Lakshmaiah Education Foundation, Vaddeswaram, AP, India. He has twenty-two years of national and international experience in teaching English at various disciplines. His doctoral thesis was on TOEFL iBT Reading Comprehension. He has thirteen research papers, and one book publication to his credit. His areas of interests are ELT, linguistics, applied linguistics, and ICT tools for language teaching. ORCiD ID: https://orcid.org/0000-0002-0383-4866

\section{References}

Ahadu, E. (2020). Novel Corona Virus Covid-19: Impact on Economic Development and Mitigating Solution for Developing Countries. Humanities and Social Sciences, 8(3), 8691. DOI: 10.11648/j.hss.20200803.11 
Arab World English Journal (AWEJ) 2nd Special Issue on Covid 19 Challenges January 2022

Ahmmad, M.R. (2014). The Problems of the Effective Classroom Teaching in Govt. Colleges in Dhaka City. Humanities and Social Sciences, 2(2), 17-22. DOI: 10.11648/j.hss.20140202.12

Al-Abdin, A., \& Costello, R. (2015). The Impact of Social Media Technologies on the Revolutions. Humanities and Social Sciences, 3(3), 116-124. DOI: 10.11648/j.hss.20150303.13

Ali, N.S. et al. (2005). Online Education: Needs Assessment for Faculty Development. The Journal of Continuing Education in Nursing, 36(1), 32-39. DOI: 10.3928/0022-0124$\underline{20050101-09}$

Allen, I. E., \& Seaman, J. (2015). Grade level: Tracking online education in the United States. Newburyport, MA: Online Learning Consortium.

Alsaif, G.A. (2019). Higher Education Students' Perceptions towards Online Class Notifications via Mobile Devices. IUG Journal of Educational and Psychological Sciences, 27(2), 2640. DOI: $10.33976 / 1443-027-002-038$

Al-Samiri, R. A. (2021). English Language Teaching in Saudi Arabia in Response to the COVID-19 Pandemic: Challenges and Positive Outcomes. Arab World English Journal (AWEJ) Special Issue on Covid 19 Challenges (1) 147-159. DOI: https://dx.doi.org/10.24093/awej/covid.11

Annamalai, N. (2019). How Malaysian Lecturers View MOOC and its Challenges. Journal of Nusantara Studies, 4(2), 144-167. http://dx.doi.org/10.24200/jonus.vol4iss2pp144-167

Bailie, J.L. (2015). Online Graduate Instruction: What Faculty Consider Reasonable In Relation to What Students Expect. MERLOT Journal of Online Learning and Teaching, 11(1), 4254.

Barnett, D.E. (2019). Full-Range Leadership as a Predictor of Extra Effort in Online Higher Education: The Mediating Effect of Job Satisfaction. Journal of Leadership Education, 18(1), 86-101. DOI:10.12806/V18/I1/R6

Benino, D., Girardi, A., \& Czarniak, P. (2011). Incorporating Online Teaching in an Introductory Pharmaceutical Practice Course: A Study of Student Perceptions within an Australian University. Pharmacy Practice, 9(4), 252-258. DOI: 10.4321/s188636552011000400011

Bolsen, T., Evans, M., \& Fleming, A.M. (2016). A Comparison of Online and Face-to-Face Approaches to Teaching Introduction to American Government. Journal of Political Science Education, 12(3), 302-317. http://dx.doi.org/10.1080/15512169.2015.1090905

Cable, J., \& Cheung, C. (2017). Eight Principles of Effective Online Teaching: A Decade-Long Lessons Learned in Project Management Education. PM World Journal: a global resource for sharing knowledge in program and project management, VI (7), 116. http://pmworldjournal.net/article/eight-principles-effective-online-teaching/

Carpenter, A. C. \& Spadaro, A. (2019). Growing Pains: Faculty Challenges and Triumphs in Moving a Communication Program Online. Journal of Educators Online, 16(2), 1-14. https://eric.ed.gov/?id=EJ1223790 
Arab World English Journal (AWEJ) 2nd Special Issue on Covid 19 Challenges January 2022

Chen, L.T., \& Liu, L. (2018). Instructor's Self-Assessment of Content Design in Online Courses. International Journal of Technology in Teaching and Learning, 14(1), 24-41.

Chen, T.L., \& Chen, T.J. (2006). Examination of Attitudes towards Teaching Online Courses Based on Theory of Reasoned Action of University Faculty in Taiwan. British Journal of Educational Technology, 37(5), 683-693. DOI:10.1111/j.1467-8535.2006.00590.x

Conaway, R.N., Easton, S.S., \& Schmidt, W.V. (2005). Strategies for Enhancing Student Interaction and Immediacy in Online Courses. Business Communication Quarterly, 68(1), 23-35 DOI: $10.1177 / 1080569904273300$

Cox, D. \& Prestridge, S. (2020). Understanding Fully Online Teaching in Vocational Education. Research and Practice in Technology Enhanced Learning, 15(16), 1-22. https://doi.org/10.1186/s41039-020-00138-4

Czerniewicz, L., Trotter, H., \& Haupt, G. (2019). Online Teaching in Response to Student Protests and Campus Shutdowns: Academics' Perspectives. International Journal of Educational Technology in Higher Education, 16(43), 1-22. https://doi.org/10.1186/s41239-019-0170-1

Daraghmeh, A., Mead, H., \& Copeland, K. (2021). English K-12 Teacher Experiences in Saudi Arabia in the Pandemic Era: A Follow-up Study of One Khbrat University Program. Arab World English Journal (AWEJ) Special Issue on Covid 19 Challenges (1) 3-20. DOI: https://dx.doi.org/10.24093/awej/covid.1

Davis, C., Greenaway, R., Moore, M., \& Cooper, L. (2019). Online Teaching in Social Work Education: Understanding the Challenges. Australian Social Work, 72(1), 34-46. https://doi.org/10.1080/0312407X.2018.1524918

Davis, N.L., Gough, M., \& Taylor, L.L. (2019). Online Teaching: Advantages, Obstacles and Tools for Getting it Right. Journal of Teaching in Travel \& Tourism, 19(3), 256-263. https://doi.org/10.1080/15313220.2019.1612313

Dutton, Y.M., Ryznar, M., Long, K. (2019). Assessing Online Learning in Law Schools: Students Say Online Classes Deliver. Denver University Law Review, 96(3), 493-534. Available at SSRN: https://ssrn.com/abstract=3242824

Fenhua, L., \& Chenhao, Q. (2016). The Building and Practicing of Teaching Mode "Students and Teacher Sharing One Stage". Humanities and Social Sciences, 4(1), 1-4. DOI: 10.11648/j.hss.20160401.11

Foster, L., Neuer C, A., \& Briggs, C. (2018). Language \& Online Learning: Inform, Inspire and Engage Virtual Learning Communities. The Journal of Counselor Preparation and Supervision, 11(1). Retrieved from https://repository.wcsu.edu/jcps/vol11/iss1/6

Glass, C.R. (2017). Self-Expression, Social Roles, and Faculty Members' Attitudes towards Online Teaching. Innovative Higher Education, 42 (3):239-252. DOI 10.1007/s10755016-9379-2

Gorsky, P., \& Blau, I. (2009). Online Teaching Effectiveness: A Tale of Two Instructors. International Review of Research in Open and Distance Learning, 10(3), 1-28. DOI: 10.19173/irrodl.v10i3.712 
Arab World English Journal (AWEJ) 2nd Special Issue on Covid 19 Challenges January 2022

Hartley, L., \& McGaughey, F. (2018). Using Online and Face-to-Face Simulations in Human Rights Tertiary Teaching: A Comparative Analysis. Journal of Human Rights Practice, 10, 125-141. DOI: 10.1093/jhuman/huy008

Joyner, S. A., Fuller, M.B., Holzweiss, P.C., Henderson, S., \& Young, R. (2014). The Importance of Student-Instructor Connections in Graduate Level Online Courses. MERLOT Journal of Online Learning and Teaching, 10(3), 436-446.

Júnior, F.R.C., \& Lemos, M.F. (2017). Do Not Close My School: Facebook, Occupations and Demonstrations for Promoting Social Change. Humanities and Social Sciences, 5(6), 222-229. DOI: 10.11648/j.hss.20170506.15

Kibaru, F. (2018). Supporting Faculty to Face Challenges in Design and Delivery of Quality Courses in Virtual Learning Environments. Turkish Online Journal of Distance Education, 19(4), 176-197. DOI: 10.17718/tojde.471915

Ladyshewsky, R.K. (2016). The Virtual Professor and Online Teaching, Administration and Research: Issues for Globally Dispersed Business Faculty. International Journal of ELearning \& Distance Education, 32(2). 1-16. Retrieved from http://www.ijede.ca/index.php/jde/article/view/985

Matthew, K.I. (2001). Student Responses to Online Course Materials. Journal of Research on Computing in Education, 33(5), 1-21.

Morrison, R. (2011). A Comparison of Online Versus Traditional Student End-of-Course Critiques in Resident Courses. Assessment \& Evaluation in Higher Education, 36(6), 627-641. DOI: 10.1080/02602931003632399

Muljana, P. S. \& Luo, T. (2019). Factors Contributing to Student Retention in Online Learning and Recommended Strategies for Improvement: A Systematic Literature Review. Journal of Information Technology Education: Research, 18, 19-57. https://doi.org/10.28945/4182

Paolo, T. D., Wakefield, J. S., Mills, L.A., \& Baker, L. (2017). Lights, Camera, Action: Facilitating the Design and Production of Effective Instructional Videos. Tech Trends, 61, 452-460. DOI 10.1007/s11528-017-0206-0

Paquette, K.R., Corbett, F.J., \& Casses, M. (2015). Student Evaluation Response Rates of Teacher Performance in Higher Education Online Classes. The Quarterly Review of Distance Education, 16(4), 71-82. https://eric.ed.gov/?id=EJ1143799

Peterson, J.L. (2016). Formative Evaluations in Online Classes. The Journal of Educators Online, 13(1), 1-24. https://eric.ed.gov/?id=EJ1087683

Power, M., \& St-Jacques, A. (2014). The Graduate Virtual Classroom Webinar: A Collaborative and Constructivist Online Teaching Strategy. MERLOT Journal of Online Learning and Teaching, 10(4), 681-696. http://jolt.merlot.org/vol10no4/Power_1214.pdf

Reeves, P.M., \& Reeves, T.C. (2008). Design Considerations for Online Learning in Health and Social Work Education. Learning in Health and Social Care, 7(1), 46-58. https://doi.org/10.1111/j.1473-6861.2008.00170.x

Rubin, B., \& Fernandes, R. (2013). Measuring the Community in Online Classes. Online Learning, 17(3). 1-29. DOI: http://dx.doi.org/10.24059/olj.v17i3.344 
Arab World English Journal (AWEJ) 2nd Special Issue on Covid 19 Challenges January 2022

Perceptions of University Faculty of Saudi Arabia towards Online Classes

Chatta, Haque \& Rao

Sher, W., Williams, A. \& Northcote, M. (2015). The Lived Experience of Online Education: Insights from Construction Management. Construction Economics and Building, 15(2), 49-62. DOI: http://dx.doi.org/10.5130/AJCEB.v15i2.4398

Stone, C., \& Springer, M. (2019). Interactivity, Connectedness and 'Teacher-Presence': Engaging and Retaining Students Online. Australian Journal of Adult Learning, 59(2), 146-169.

Tanis, C.J. (2020). The Seven Principles of Online Learning: Feedback from Faculty and Alumni on its Importance for Teaching and Learning. Research in Learning Technology, 28, 125. DOI: https://doi.org/10.25304/rlt.v28.2319

Vonderwell, S.K., \& Boboc, M. (2013). Promoting Formative Assessment in Online Teaching and Learning. TechTrends, 57(4), 22-27. https://doi.org/10.1007/s11528-013-0673-x

Wallace, R.M. (2003). Online Learning in Higher Education: A Review of Research on Interactions among Teachers and Students. Education, Communication \& Information, 3(2), 241-280. DOI: 10.1080/1463631032000092046

Wong, L. \& Tatnall, A. (2009). The Need to Balance the Blend: Online Versus Face-to-Face Teaching in an Introductory Accounting Subject. Issues in Informing Science and Information Technology, 6. 309-322. DOI: 10.28945/3324

Wyss, V.L., Freedman, D., \& Siebert, C.J. (2014). The Development of a Discussion Rubric for Online Courses: Standardizing Expectations of Graduate Students in Online Scholarly Discussions. TechTrends, 58(2), 99-107. https://doi.org/10.1007/s11528-014-0741-x

Yang, C.C.R. (2019). Student Responses to Online Peer Assessment in Tertiary English Language Classrooms. The Electronic Journal for English as a Second Language, 23(1), 1-24. https://eric.ed.gov/?id=EJ1215551

Appendices

Appendix A: Mean, mode, standard deviation, skewness and kurtosis analysis of each item

\begin{tabular}{|l|l|l|l|l|l|l|}
\hline $\begin{array}{l}\text { S.N } \\
\mathrm{o}\end{array}$ & Item Description & Mean & Mode & $\begin{array}{l}\text { Std. } \\
\text { Deviation }\end{array}$ & Skewness & Kurtosis \\
\hline $\begin{array}{l}\text { Item } \\
1\end{array}$ & Students are not serious during online classes & 3.59 & 4 & 1.07 & -0.49 & -0.71 \\
\hline $\begin{array}{l}\text { Item } \\
2\end{array}$ & $\begin{array}{l}\text { Interacting with students during online classes is } \\
\text { difficult }\end{array}$ & 3.62 & 4 & 1.09 & -0.84 & -0.09 \\
\hline $\begin{array}{l}\text { Item } \\
3\end{array}$ & $\begin{array}{l}\text { Monitoring students and their non-academic } \\
\text { activities during online classes is a big issue. }\end{array}$ & 4.10 & 4 & 0.96 & -1.37 & 1.75 \\
\hline $\begin{array}{l}\text { Item } \\
4\end{array}$ & $\begin{array}{l}\text { Online classes can have physical and mental } \\
\text { health issues. }\end{array}$ & 3.30 & 4 & 1.12 & -0.28 & -0.90 \\
\hline $\begin{array}{l}\text { Item } \\
5\end{array}$ & $\begin{array}{l}\text { Students miss peer learning and peer interaction } \\
\text { during the online classes }\end{array}$ & 3.80 & 4 & 1.03 & -1.11 & 0.74 \\
\hline $\begin{array}{l}\text { Item } \\
6\end{array}$ & $\begin{array}{l}\text { Monitoring the testing process is not effective in } \\
\text { online mode }\end{array}$ & 3.89 & 4 & 1.14 & -0.89 & -0.20 \\
\hline Item & The learning process is not effective in online & 3.37 & 4 & 1.10 & -0.33 & -0.86 \\
\hline
\end{tabular}

Arab World English Journal

www.awej.org

ISSN: 2229-9327 
Arab World English Journal (AWEJ) 2nd Special Issue on Covid 19 Challenges January 2022

Perceptions of University Faculty of Saudi Arabia towards Online Classes

Chatta, Haque \& Rao

\begin{tabular}{|l|l|l|l|l|l|l|}
7 & mode & & & \\
\hline $\begin{array}{l}\text { Item } \\
8\end{array}$ & $\begin{array}{l}\text { Online teaching should be used only in } \\
\text { emergency. }\end{array}$ & 3.68 & 4 & 1.12 & -0.65 & -0.41 \\
\hline $\begin{array}{l}\text { Item } \\
9\end{array}$ & Online teaching is boring and monotonous & 3.17 & 4 & 1.07 & -0.02 & -1.06 \\
\hline $\begin{array}{l}\text { Item } \\
10\end{array}$ & Internet issues are very frustrating & 3.65 & 4 & 1.05 & -0.89 & 0.27 \\
\hline $\begin{array}{l}\text { Item } \\
11\end{array}$ & Class size is not an issue in online mode & 3.41 & 4 & 1.23 & -0.60 & -0.74 \\
\hline $\begin{array}{l}\text { Item } \\
12\end{array}$ & $\begin{array}{l}\text { Teaching can be continued in extreme situations } \\
\text { like pandemics, war, etc. }\end{array}$ & 4.17 & 4 & 0.86 & -1.68 & 4.21 \\
\hline $\begin{array}{l}\text { Item } \\
13\end{array}$ & $\begin{array}{l}\text { Online teaching is a substitute for regular } \\
\text { teaching }\end{array}$ & 1.76 & 1 & 0.90 & 1.08 & 0.37 \\
\hline $\begin{array}{l}\text { Item } \\
14\end{array}$ & $\begin{array}{l}\text { The traveling time saved for faculty and students } \\
\text { is worth it }\end{array}$ & 3.19 & 4 & 1.09 & -0.26 & -0.88 \\
\hline $\begin{array}{l}\text { Item } \\
15\end{array}$ & Online teaching is convenient and flexible & 3.33 & 4 & 1.10 & -0.42 & -0.64 \\
\hline
\end{tabular}

Appendix B: Relation of nationality, gender and prior experience for each item.

\begin{tabular}{|l|l|l|l|l|l|l|l|l|l|l|l|l|}
\hline S.No & \multicolumn{4}{|c|}{ Nationality } & \multicolumn{4}{c|}{ Gender } & \multicolumn{4}{c|}{ Prior experience } \\
\hline & Mean & SD & t & Sig. & Mean & SD & T & Sig. & Mean & SD & t & Sig. \\
\hline Item 1 & 3.62 & 1.03 & 0.386 & 0.7 & 3.61 & 1.08 & 0.45 & 0.654 & 3.39 & 1.15 & -1.28 & 0.203 \\
\hline Item 2 & 3.60 & 1.07 & -0.306 & 0.76 & 3.61 & 1.13 & -0.338 & 0.736 & 3.35 & 1.17 & -1.635 & 0.105 \\
\hline Item 3 & 4.17 & 0.83 & 1.311 & 0.193 & 4.10 & 1.00 & 0.023 & 0.982 & 3.81 & 1.19 & -2.059 & 0.042 \\
\hline Item 4 & 3.47 & 1.08 & 2.876 & 0.005 & 3.34 & 1.10 & 0.944 & 0.348 & 2.90 & 1.19 & -2.423 & 0.017 \\
\hline Item 5 & 3.78 & 1.01 & -0.243 & 0.808 & 3.78 & 1.07 & -0.382 & 0.703 & 3.45 & 1.23 & -2.267 & 0.026 \\
\hline Item 6 & 3.90 & 1.06 & 0.066 & 0.947 & 3.84 & 1.14 & -1.46 & 0.147 & 3.45 & 1.23 & -2.663 & 0.009 \\
\hline Item 7 & 3.40 & 1.05 & 0.462 & 0.645 & 3.38 & 1.14 & 0.305 & 0.761 & 3.03 & 1.14 & -2.066 & 0.041 \\
\hline Item 8 & 3.74 & 1.05 & 1.022 & 0.309 & 3.67 & 1.15 & -0.148 & 0.882 & 3.39 & 1.20 & -1.754 & 0.083 \\
\hline Item 9 & 3.18 & 1.04 & 0.079 & 0.937 & 3.13 & 1.07 & -1.218 & 0.226 & 2.71 & 1.01 & -3.005 & 0.003 \\
\hline Item 10 & 3.72 & 0.99 & 1.149 & 0.253 & 3.62 & 1.06 & -0.86 & 0.392 & 3.52 & 1.00 & -0.847 & 0.399 \\
\hline Item 11 & 3.36 & 1.31 & -0.708 & 0.481 & 3.33 & 1.27 & -1.973 & 0.051 & 3.29 & 1.24 & -0.633 & 0.528 \\
\hline Item 12 & 4.21 & 0.84 & 0.634 & 0.528 & 4.18 & 0.86 & 0.342 & 0.733 & 3.97 & 1.08 & -1.622 & 0.108 \\
\hline Item 13 & 1.74 & 0.90 & -0.271 & 0.787 & 1.67 & 0.85 & -2.803 & 0.006 & 1.87 & 1.06 & 0.838 & 0.404 \\
\hline Item 14 & 3.21 & 1.12 & 0.179 & 0.859 & 3.22 & 1.05 & 0.621 & 0.536 & 3.26 & 1.00 & 0.387 & 0.699 \\
\hline Item 15 & 3.37 & 1.12 & 0.68 & 0.498 & 3.37 & 1.11 & 1.056 & 0.293 & 3.58 & 1.15 & 1.531 & 0.129 \\
\hline Item 16 & 3.01 & 0.97 & -0.127 & 0.899 & 3.04 & 0.92 & 0.759 & 0.45 & 3.13 & 0.81 & 0.785 & 0.435 \\
\hline
\end{tabular}

Appendix C: Influence of designation and university for each item

\begin{tabular}{|c|c|c|}
\hline S.No. & Designation & University \\
\hline
\end{tabular}

Arab World English Journal

www.awej.org

ISSN: 2229-9327 
Arab World English Journal (AWEJ) 2nd Special Issue on Covid 19 Challenges January 2022

Perceptions of University Faculty of Saudi Arabia towards Online Classes

Chatta, Haque \& Rao

\begin{tabular}{|c|c|c|c|c|}
\hline & $\mathrm{F}$ & Sig. & $\mathrm{F}$ & Sig. \\
\hline Item 1 & 1.299 & 0.279 & 0.472 & 0.702 \\
\hline Item 2 & 0.807 & 0.493 & 0.884 & 0.452 \\
\hline Item 3 & 0.579 & 0.63 & 1.729 & 0.166 \\
\hline Item 4 & 1.389 & 0.251 & 1.066 & 0.367 \\
\hline Item 5 & 0.863 & 0.463 & 0.511 & 0.676 \\
\hline Item 6 & 0.464 & 0.708 & 0.157 & 0.925 \\
\hline Item 7 & 1.274 & 0.288 & 0.893 & 0.447 \\
\hline Item 8 & 0.681 & 0.566 & 1.166 & 0.327 \\
\hline Item 9 & 0.274 & 0.844 & 1.586 & 0.197 \\
\hline Item 10 & 0.162 & 0.922 & 1.012 & 0.391 \\
\hline Item 11 & 1.733 & 0.165 & 2.268 & 0.085 \\
\hline Item 12 & 1.482 & 0.224 & 0.271 & 0.846 \\
\hline Item 13 & 0.376 & 0.771 & 1.163 & 0.328 \\
\hline Item 14 & 1.401 & 0.247 & 0.243 & 0.866 \\
\hline Item 15 & 0.697 & 0.556 & 0.543 & 0.654 \\
\hline
\end{tabular}

Appendix D: Relation of satisfaction, replacement and future mode for each item

\begin{tabular}{|l|l|l|l|l|l|l|l|l|l|l|l|l|}
\hline S.No. & \multicolumn{4}{l}{ Satisfaction } & \multicolumn{4}{l|}{ Replacement } & \multicolumn{3}{l|}{ Future mode } \\
\hline & Mean & SD & $\mathrm{t}$ & Sig. & Mean & $\mathrm{SD}$ & $\mathrm{t}$ & Sig. & Mean & $\mathrm{SD}$ & $\mathrm{t}$ & Sig. \\
\hline Item 1 & 3.37 & 1.05 & -2.861 & 0.005 & 2.88 & 0.93 & -3.118 & 0.002 & 3.86 & 1.14 & 2.925 & 0.004 \\
\hline Item 2 & 3.32 & 1.12 & -3.855 & 0 & 2.59 & 1.00 & -4.673 & 0 & 3.95 & 0.99 & 3.551 & 0.001 \\
\hline Item 3 & 3.89 & 1.00 & -2.952 & 0.004 & 2.94 & 1.14 & -6.461 & 0 & 4.32 & 0.87 & 2.663 & 0.009 \\
\hline Item 4 & 3.15 & 1.15 & -1.763 & 0.081 & 2.18 & 0.81 & -5.051 & 0 & 3.65 & 1.08 & 3.732 & 0 \\
\hline Item 5 & 3.57 & 1.03 & -3.032 & 0.003 & 2.94 & 1.20 & -4.002 & 0 & 4.05 & 0.91 & 2.908 & 0.004 \\
\hline Item 6 & 3.68 & 1.19 & -2.595 & 0.011 & 2.88 & 1.45 & -4.351 & 0 & 4.11 & 1.03 & 2.144 & 0.034 \\
\hline Item 7 & 3.12 & 1.13 & -3.081 & 0.003 & 2.29 & 0.77 & -4.863 & 0 & 3.79 & 0.98 & 4.741 & 0 \\
\hline Item 8 & 3.49 & 1.19 & -2.26 & 0.026 & 2.59 & 1.06 & -4.849 & 0 & 4.18 & 0.91 & 5.714 & 0 \\
\hline Item 9 & 2.83 & 0.98 & -4.683 & 0 & 2.53 & 0.94 & -2.811 & 0.006 & 3.58 & 0.96 & 4.684 & 0 \\
\hline Item 10 & 3.60 & 1.01 & -0.634 & 0.528 & 3.00 & 1.12 & -2.881 & 0.005 & 3.95 & 0.91 & 3.335 & 0.001 \\
\hline Item 11 & 3.46 & 1.21 & 0.577 & 0.565 & 3.41 & 1.18 & 0.015 & 0.988 & 3.53 & 1.26 & 1.088 & 0.279 \\
\hline Item 12 & 4.22 & 0.86 & 0.628 & 0.532 & 3.88 & 0.99 & -1.551 & 0.124 & 4.30 & 0.71 & 1.642 & 0.104 \\
\hline Item 13 & 1.83 & 0.94 & 1.083 & 0.282 & 3.06 & 0.83 & 8.48 & 0 & 1.49 & 0.85 & -3.514 & 0.001 \\
\hline Item 14 & 3.46 & 1.02 & 3.408 & 0.001 & 3.41 & 1.23 & 0.896 & 0.372 & 3.09 & 1.12 & -1.1 & 0.274 \\
\hline Item 15 & 3.60 & 1.07 & 3.434 & 0.001 & 3.88 & 0.99 & 2.32 & 0.022 & 2.93 & 1.12 & -4.493 & 0 \\
\hline
\end{tabular}

\section{Arab World English Journal}

ISSN: 2229-9327 